Working Paper 98-31

Business Economics Series 03

Mars 1998
Departamento de Economía de la Empresa

Universidad Carlos III de Madrid

Calle Madrid, 126

28903 Getafe (Spain)

Fax (341) 624-9608

\title{
VOGUES IN MANAGEMENT ACCOUNTING RESEARCH *
}

\author{
Salvador Carmona* and Isabel Gutiérrez ${ }^{* *}$
}

\begin{abstract}
There exists growing interest in investigating the status and evolution of accounting research. Despite our greater lore about the extant lines of inquiry in the accounting discipline, little is still known about the cross-national dynamics of accounting research ideas. This paper aims at addressing the ebb and flow of management accounting research fashions among national groupings of accounting scholars as well as the underlying reasons that differentiate earlier from later adopters of research fashions. Drawing on the institutional sociology and the management fashion literatures, definitions of both the accounting organizational field and fashions of research are firstly provided. Activity-Based Costing $(\mathrm{ABC})$ exemplifies our understanding of management accounting research fashions. Our results found support for the notions that national communities with high research profile (i) are less vulnerable to the effects of research fashions and (ii) are earlier adopters of research fashions than their counterparts with lower research profile. Lastly, we posit some suggestions for future work aiming at investigating the traveling of research ideas in the management accounting field.
\end{abstract}

* This research was funded by the CICYT (SEC 96-0637) and by the DGICYT (PB 95-0282). The autors have benefited from discussions with Keith Robson. Suggestions made by the participants at the Euroconference on "Mapping Difference in Practices and Theories of Management Control" (Palermo, 7-11 December 1997), the Workshop on Management ControlRaymond Konopka Memorial (Universidad Carlos III, 15-16 December 1997), and by Mahmoud Ezzamel are gratefully acknowledged.

"Universidad Carlos III de Madrid, Departamento de Economía de la Empresa, C/ Madrid, 126, 28903 Getafe (Madrid). Fax: +34.1.6249608. Email: scarmona@eco.uc3m.es

"*Universidad Carlos III de Madrid, Departamento de Economía de la Empresa, C/ Madrid, 126, 28903 Getafe (Madrid). Fax: +34.1.6249608 Email: isagut@eco.uc3m.es 
There exists growing interest in investigating the status and evolution of accounting research. The accounting academia undergoes a process of structuration (DiMaggio, 1983) which in the main involves increasing interactions among accounting academics. The complexity of such process mobilizes considerable efforts to screen the extant patterns of accounting research. Panozzo (1997) analyzed models of doctoral training in European and North American universities. After comparing mainstream North American accounting research with the variety of methodological approaches that characterize the European tradition, he concluded that the latter fits well into Whitley's (1984) category of fragmented adhocracy; that is, the European accounting community is depicted as having low dependence between researchers and high task uncertainty. Zambon (1996) edited a series of special issues of The European Accounting Review which explored the relationship between accounting and business economics traditions in several European countries. The spread of research traditions ranged from countries where accounting emerged from, and is still ingrained in the business economics field (e.g., Finland, see Näsi and Näsi, 1997) to others which exhibited a vague relation between such disciplines (e.g., United Kingdom, see Napier, 1996). Recent studies of Shields (1997) and Atkinson et al. (1997) have also brought issues of reviews and future research directions in the more concrete field of management accounting. First, Shields (1997) reviewed the contributions of North American scholars to six top accounting journals and identified six areas for research: changes in management accounting, horizontal accounting, strategic accounting, organizational accounting, and integrative research. Second, Atkinson et al. (1997) discussed the 1995 report of the Management Accounting Section research committee of the American Accounting Association (AAA). They focused on three specific areas "that have promising for expanding the current knowledge base in management accounting": management accounting's role in organizational change, the interaction between accounting and organizational structure, and the role of accounting information in supporting decision making. By casting light on the overall features of accounting research, the specifics of areas such as management accounting, and the existing idyosincratic traditions within individual countries, these studies have led to a greater lore about the lines of inquiry in the accounting discipline. In spite of our increasing understanding about the dynamics of accounting research, little is still 
known about the accounting research process itself (see Arrington and Schweiker, 1992) and, particularly, how research ideas ebb and flow across countries and which characteristics distinguish earlier from later adopters of research topics.

In this paper we focus on the dissemination of management accounting research fashions across academic communities of different countries. We characterise such fashions as either research agendas drawing on innovative professional practices or as academic developments suitable to be implemented in the realm of practice without further significant adaptation. According to this definition, research fashions are intertwined with professional practice and this link implies two additional considerations. First, research fashions are particularly suited to move across countries if they are not entangled in their primary socioeconomic contexts. Second, research vogues sharply differentiate from the elegant, academic research which purposely targets leading accounting journals (Lee, 1989). By investigating fashions of research in management accounting we seek to contribute to (i) our understanding of their dynamics, especially by analysing which conditions influence academics to adopt and swing them, and (ii) our understanding of the characteristics which help to explain the observational lag in the adoption of fashions between countries. Empirical evidence supporting this study has been gathered from observations relating to the British and Spanish accounting academic communities during the period 1987-1996.

We differentiate research fashions from knowledge core (see Cole, 1983: 114115). First, research fashions are a constitutive element of the "research frontier", a concept which encompassess all work currently published by active researchers in a given discipline. In contrast, knowledge core only embraces the small number of ideas which are used and assessed as important long after publication (e.g., 25 years). Second, similar to the behaviour of aesthetic fashions, research fashions are assumed to suddenly and dramatically hit a particular area of interest. Therefore, one can expect that research fashions show a bell-shaped pattern and a short-term life cycle as Abrahamson (1996) found for management fashions. Activity-Based Costing (ABC) exemplifies our understanding of a management accounting research fashion, whose impact on journals indexed in the ABI Inform University Microfilm Database is shown in Figure 1. 
Contributions of the new institutional sociology are of considerable interest to this paper. Institutional theorists have delved into the underlying reasons as to why innovations are disseminated among organizations (Meyer and Rowan, 1977). This literature, we argue, provides a relevant framework to explore how management accounting research fashions are adopted by researchers affiliated to higher education organizations of different countries. A basic tenet of the institutional sociology is that institutions exert strong pressures on organizations to behave rationally. Organizations operating in similar environments, thus, experience comparable demands and tend to look like each other or, as new institutionalists put it, become isomorphic (DiMaggio and Powell, 1983). These authors distinguish three types of institutional isomorphism. First, coercive isomorphism refers to pressures exerted on organizations by organizations to which they are dependent on. Coercive isomorphism is illustrated by the influence of the state on an organization, especially through the enactment of legislations that impinge organizational actions. The structure of higher education organizations is highly shaped by the strong influence of the state, as shown by Frey (1993) in his study of the market for economics academics. Second, mimetic isomorphism concerns the imitation of practices implemented by successful organizations. It is argued that organizations mimic others when either their goals are ambiguous or when there exists high levels of environmental uncertainty. Lastly, normative isomorphism is a consequence of pressures exerted by the professions to normalize organizational actions.

Institutions, however, are not monolithic and do not always elicit compliance and agreement from organizations (see Oliver, 1991; Mezias and Scarseletta, 1994). Organizational response to external demands depends on the tangible and intangible resources supplied to the firm by constituents, and this in turn will be subject to the degree of such pressures. In the case of strong institutional pressures, conforming organizations garner social support by avoiding questions about their actions (Meyer and Rowan, 1977; Meyer and Scott, 1983) and heightening their legitimacy (Oliver, 1991), and this in turn increases their access to resources and enhances their life chances.

Educational organizations illustrate the case of a population heavily influenced by its institutional environment (Meyer and Rowan, 1977; Frey, 1993). Zajac and 
Kraatz (1993) contend that these organizations operate in mature and well-defined environments and embrace them as open systems in intense interaction with their environment. Educational organizations, in short, "are forced by pressures for conformity to adopt structures that have the support and endorsement of key agencies in the institutional environment" (Rowan, 1982: 260). Accordingly, institutional sociologists have developed extensive empirical research to illuminate how educational organizations interact with their institutional environments. For the purposes of this paper, we are interested in investigations based on the institutional sociology which address the dissemination of innovations between educational organizations.

First, Rowan (1982) traced the histories of three different administrative services from their implementation to their diffusion and retention at the local level on school districts in California. He drew on the concept of "balanced environment", which embraced "the establishment of ideological consensus and harmonious working relations among legislatures, publics, regulatory agencies, and professional associations" (pp. 259-260), to successfully test the notion that administrative services supported by balanced institutional environments diffused more widely and were more stably retained at the local level than those endorsed by imbalanced institutional environments. Second, Genell (1997), in a rare study of its kind, conducted an investigation informed by both the model of translation (see Latour, 1986; Callon, 1986; Ezzamel, 1994) and institutional sociology to analyse the diffusion of Western business education models into Polish higher education organizations. She concluded that the latter did not just mimic US ideas and practices in an unreflective manner but rather took an active role in the process of adaptation of the US business education model to the Polish environment. Lastly, Zajac and Kraatz (1993) examined the process of strategic restructuring in the US higher education industry over a 20 years period. They found that such process was the consequence of a rationally adaptive change, characterized by a thorough awareness of the need to change, the development of extensive deliberations about how to undertake the organizational restructuring, and the observation of performance improvements for those organizations that implemented the change. They concluded that restructuring organizations were not enmeshed in a process of mechanical imitation of their counterparts but in a reflective 
adaptation to environmental changing conditions. In sum, these investigations informed by the institutional sociology provide interesting insights into the process of dissemination of administrative and teaching innovations among organizations which, we contend, are instrumental in ascertaining the emergence and development of management accounting research fashions in these organizations.

The remainder of the paper is structured as follows. First, some propositions are derived from a review of the management fashion and institutional sociology literatures. Second, the sources of data and the operationalization of the variables are discussed. This is followed by the presentation of the results. Lastly, the paper concludes with the discussion of results, implications, limitations, and suggestions for future research.

\section{RESEARCH FASHIONS}

\section{The unit of analysis}

The notion of organizational field constitutes the unit of analysis of institutional theorists (DiMaggio and Powell, 1983). An organizational field embodies an area of institutional life and comprises organizations such as suppliers, customers, and competitors. As DiMaggio and Powell (1983) point out, the structure of particular organizational fields cannot be a priori determined but should be the result of ad hoc analyses. For the purposes of this paper, we are interested in operationalizing the concept of organizational field such as being suitable for analysing the ebb and flow of research fashions. In this guise, higher education organizations of Western countries, we argue, compose the core of the organizational field. The field is also formed by students enrolled in Western universities, professional associations of certified accountants (e.g., Institute of Chartered Accountants in England and Wales, American Institute of Certified Public Accountants), academic associations (e.g., European Accounting Association (EAA) and American Accounting Association), regulatory bodies (e.g., the Financial Accounting Standards Board), consultancy and auditing firms, and companies hiring accounting graduates. Such comprehensive definition of the organizational field rests on the development in tandem of a process of structuration of the accounting academic community and the globalization of the economy.

The structuration of organizational fields involves five distinctive elements (see 
DiMaggio, 1983). First, organizations in the field increase their interactions. Although we concur with the notion that research published in major academic journals still has a strong local character (see Lukka and Kasanen, 1996), the degree of interaction among accounting scholars experienced a steady increase over the past fifteen years. Supporting evidence for this argument comes from the growing global profile of events such as the conferences of the EAA, the Interdisciplinary Perspectives in Accounting Conference, or the World Congress of Accounting Historians, as well as the annual doctoral colloquium of the EAA and the doctoral consortium of the American Accounting Association (AAA). Interaction among scholars participating in those events is subsequently followed by the constitution of international research networks (e.g., the TMR programme of the European Commission), the development of stays of research in centers of excellence (e.g., American, British, and Canadian universities are regular recipients of foreign researchers), the increasing internationalization of the editorial boards of academic journals, and the access to transnational research funding (e.g., the European Commission funds research networks involving European and Latinamerican scholars). Such boost in interactions within the field, we expect, will propel a pervasive shift from local to global focus in the contents of leading academic journals. Second, increase in the flow of information from and within organizations in the field is evidenced by the easier access of scholars to electronic databases and communication networks (e.g., Internet, e-mail). Third, the emergence of a structure of domination is indicated by the widespread recognition of Anglo-Saxon accounting research as the canon of the discipline; the preeminence of Anglo-Saxon universities in the Western domain, the regular participation of scholars affiliated to these organizations as keynote speakers in international conferences, their outstanding records in the citation index (see Brown, 1996), and their overwhelming editorship of top-tier, premier outlets are among the supportive arguments of the notion that the field is witnessing a structure of domination formed by Anglo-Saxon higher education centres. Fourth, the deployment of a pattern of coalition is shown by the recent constitution of regional and national associations of accounting academics such as the EAA and the Spanish Association of Accounting Academics, respectively, as well as the sustained growth in accounting journals (Brown and Huefner, 1994). Lastly, the field is being shaped by the ideology long embodied by the Anglo-Saxon 
community. It comprises the production of evidence-based knowledge (Zeff, 1989), publication in journals subject to refereed process (Gray and Helliar, 1994), and the preemince of research over teaching as a critical factor in promotion and tenure (Schultz, Meade and Khurana, 1989; Puxty, Sikka and Willmott, 1994). In short, we contend that the core of the accounting organizational field is formed by higher education organizations of Western countries and that the field undergoes a process of structuration which denotes the prominent role of its Anglo-Saxon constituents.

Constituents of the organizational field are not homogeneous across countries, as shown by Abrahamson (1996) in his study of the diffusion of management fashions. Heterogeneity within the field is to some extent attributed to the influence of the state, which enacts regulations that strongly shape the structure of higher education organizations. Accordingly, coercive isomorphism renders significant dissimilarities across educational organizations of different Western countries (see Frey and Eichenberger, 1993), and this in turn deploys considerable similarities among organizations of the same country. These arguments lead us to highlight an observational level of somewhat scattered national groupings of constituents within the organizational field. Seen in such perspective, we shall approach the ebb and flow of management accounting research fashions across countries by focusing on social actors formed by the national communities of constituents within the defined organizational field.

\section{Impact of Research Fashions and the Research Profile of National Groupings}

Imitation is assumed to occur within an organizational field (DiMaggio and Powell, 1983). Interaction among field members leads to shared thoughts that spill over constituents. Organizations facing environmental uncertainty or goal ambiguity borrow these share thoughts and mimic practices from more reliable firms. Put differently, "organizations imitate when they have more confidence in the history of others than in their own" (Sevón, 1996: 54). Therefore, imitators want to become like someone else and, prefereably, like someone who is conceived of as successful (Genell, 1997: 228-229). This process of mimetic isomorphism, thus, makes imitators to resemble successful organizations, and this enhances their legitimacy and avoids questions about their behavior. Imitation, in short, is not solely dictated by technical criteria but rather concerns legitimacy and power (Carruthers, 1995). 
The adoption of management fashions exemplifies the process of organizational imitation. Organizations under conditions of uncertainty are prone to implement models promoted by fashion-setting organizations (Abrahamson, 1991: 589). Fashion followers, thus, attempt to improve their image of innovativeness by implementing management techniques deemed as innovative. Therefore, there exists a demand for management fashions and management fashion setters attemp to satisfy such demand (Abrahamson, 1996). In light of these arguments, organizations experiencing low environmental uncertainty, explicit goals and good performance will be less vulnerable to the effects of management fashions than their counterparts suffering adversarial conditions.

National research communities may be differentiated according to their research profile. Researchers purport to get read and not just published (Schneider, 1995). It follows that academics target their papers to journals providing them with great visibility. In this guise, scholars publishing in top academic journals heighten their reputation (Whitley, 1984: 33-34; Brown and Huefner, 1995: 224), and this in turn enhances their likelihood of promotion to tenured positions, higher salaries and greater access to research funding (Gómez-Mejía and Balkin, 1992). Analagous reasoning may be extended from the perspective of the individual researcher to the national grouping level; high profile research groupings increase their prestige by making regular contributions to respected academic outlets, and this in turn influences policy-makers' decisions on the allocation of research funding among competing fields (Pfeffer, 1993). It also improves the probability of fund rising for research proposals, as well as for low-teaching load positions in higher education organizations.

Communities striving for publishing in top academic journals are involved in longterm research projects and, in concordance with the suggestions of the institutional and management fashions literatures, are expected to be less vulnerable to the effects of management accounting research fashions than counterparts with lower research profile. In sum, high profile research groupings are assumed to exhibit consistency and continuity in their research patterns and, thereby, will be poorly affected by the sudden impact of management accounting research fashions. This reasoning lead us to the following proposition:

Proposition 1: National groupings with high research profile are less 
vulnerable to the effects of management accounting research fashions than their counterparts with lower research profile.

\section{Adoption Lag of Research Fashions and Research Profile of National Groupings}

Innovations are not uniformly disseminated among field members.

Accordingly, it is appropriate to distinguish between the behavioural patterns of early and late adopters. The spread of innovations among organizations diminishes the competitive edge of early adopters and, then, legitimacy becomes the driving force to adopt past innovations (Meyer and Rowan, 1977). Moreover, whereas early adopters discriminate among a portfolio of innovations and assume the risk of eventual failures, late adopters follow a bandwagon effect (Abrahamson, 1991, 1996). By being uncertainty adverse, late adopters imitate available innovations in order to diminish low performance risk. This decision pattern is embraced by Bikhchandani, Hirshleifer and Welch (1992: 994) under the notion of information cascade, which refers to the situation in which "it is optimal for an individual, having observed the actions of those ahead of him, to follow the behavior of the preceding individual without regard to his own information."

The notion of information cascade is useful in explaining the cross-national imitation of innovations. Organizations have strong incentives to await for the dissemination of innovations (or management fashions) in countries different from theirs before imitating such innovations. By becoming late adopters at the global level and early adopters at the domestic one, these organizations enjoy both the benefits of the bandwagon effect (late adopters) and the advantages of being early adopters in their domestic domain, that is, "social distinction, the demonstration of alert leadership, or at least not lethargy, in recognizing and adopting that which will in due time become widely approved" (Stigler and Becker, 1977: 88). This cross-national behavior, in turn, brings about a swing of fashions by early (global level) adopters as they can no longer enjoy the technical and legitimate benefits attached to management fashions.

Timing the dissemination of management accounting research fashions is coupled with the research profile of national groupings. In line with the arguments provided by the institutional and management fashion literatures, we argue that early adopters of management accounting research fashions discriminate among the 
portfolio of research topics offered by both management accounting fashion setters and their present research projects. The motivation for adopting a research fashion rests on its expected performance capabilities, that is, on its potentials to produce publishable outcome. Such informed choice can be made by scholars holding high research records. In contrast, late adopters follow an information cascade pattern; they make their decision on the basis of the information provided by the decision of early adopters. Late adopters, thus, rely on the research superiority and discriminant capabilities of early adopters when embracing a management accounting research fashion. In light of these arguments, we have:

Proposition 2: National groupings with high research profile are earlier adopters of management accounting research fashions compared to their counterparts with lower research profile.

\section{SOURCES OF DATA AND OPERATIONALIZATION OF THE VARIABLES}

The research profile of the national groupings which forms the organizational field was measured by counting the contribution of the individual countries to 13 leading accounting journals. We concur with Parker, Guthrie and Gray (1997) in that these categorisations are inevitably value-laden and subjective. However, our categorisation of well-regarded journals does not constitute the core of our study because the debate of measures of research performance is far beyond the scope of this paper (see Humphrey, Moizer and Owen, 1997). In contrast, we attempt to explore the mobility of management accounting research fashions across national groupings. Our choice of journals was informed by the following criteria (i) we selected journals with an unequivocal accounting focus. Journals, thus, incidentally publishing accounting research but lacking a genuine accounting aim were excluded from our list (e.g., management journals such as Journal of Management Studies, The Scandinavian Journal of Management, (ii) we selected journals with either a general or a management accounting focus because we intended to enhance our understanding of management accounting research fashions. Journals aiming at the publication of research pieces dealing with other specific fields of accounting were, thus, excluded from our list (e.g., accounting history journals: The Accounting Historians Journal), (iii) we selected refereed research journals because we intended to measure the research profile of different national groupings. Consequently, professional journals 
were excluded from our list (e.g., Journal of Cost Management), and (iv) we selected journals published by national professional associations only if they were unequivocally regarded as premier outlets (e.g., The Accounting Review, published by the American Accounting Association; Accounting and Business Research, published by the Institute of Chartered Accountants in England and Wales). In contrast, wellrespected journals published by national professional associations, but not joining the èlite of world-class outlets, were excluded from our list (e.g., the British Accounting Review, published by the British Accounting Association). In this manner, we avoid to overdraw the contribution of the country in which the professional association is based.Our list of journals was, therefore, formed by the following: Abacus; Accounting and Business Research; Accounting, Auditing and Accountability Journal; Accounting, Organizations and Society; The Accounting Review; Contemporary Accounting Research; Critical Perspectives on Accounting; The European Accounting Review; Journal of Accounting and Economics; Journal of Accounting Research; Journal of Business Finance and Accounting; Journal of Management Accounting Research; and Management Accounting Research. The nationality of the authors was measured through their affiliation. Co-authored papers were adjusted by the number of authors; for example, a co-authored paper by three individuals of different countries accounted $1 / 3$ for each country. Lastly, data were collected through the analysis of each individual paper published in the abovementioned outlets.

Our study of management accounting research fashions focuses on the particular case of Activity-Based Costing ( $A B C)$. $A B C$, we argue, is consistent with the definition of research fashion; it was an innovative management accounting practice (see Cooper and Kaplan, 1990) that pervaded the academic domain to become a research agenda (see Shields, 1997; Atkinson et al., 1997 for recent assessments of $\mathrm{ABC}$ as a management accounting research topic). Another perspective of $\mathrm{ABC}$ as a management accounting research fashion is shown in Figure 2 which measures the proportion of $\mathrm{ABC}$-focused papers concerning the total of management accounting articles indexed in the $A B I$ Inform University Microfilm Database. The data in that figure supports the bell-shaped pattern attributed to fashions (see Abrahamson, 1991, 1996).

We collected data from the ABI Inform University Microfilm Database to 
account for the effects of $\mathrm{ABC}$ on the research communities of individual countries. The influence of $\mathrm{ABC}$ was measured through the proportion of $\mathrm{ABC}$-focused papers as a percentage of the total of management accounting-focused papers. The bias of the $A B I$ database towards Anglophone countries, however, forced us to also consider the entire population of Spanish accounting journals: Actualidad Financiera, Partida Doble, Revista Española de Financiación y Contabilidad, and Técnica Contable, to ascertain the effects of $\mathrm{ABC}$ on the Spanish academic community.

We collected data for the period 1987 to 1996 because it comprises the genesis and development of $\mathrm{ABC}$ as a management accounting research fashion.

\section{RESULTS}

High and low research profile communities are differentiated by the extent of their contributions to the 12 accounting journals used in this paper. The data in Table 1 suggest that a small group of Anglo-Saxon countries (USA, UK, Australia, and Canada) account for the largest share of publications (88.61\%), especially due to the overwhelming contribution of USA (55.05\%) and UK (21.04\%) academics. Although the data in Table 1 suggest that other countries are increasing their share of publications (e.g., see the 1996 results of Denmark, Finland, France, Germany), nonAnglo-Saxon countries contribute less significantly to publications in top journals; the column of totals in Table 1 shows that no other European country reaches $1 \%$ of total papers published.

\section{INSERT TABLE 1 ABOUT HERE}

Our choice of UK and Spain to study the effects of $\mathrm{ABC}$ on their accounting academic communities was informed by the following arguments. First, the $\mathrm{ABC}$ system was not initiated in any of those countries and, thus, both countries could be described in this context as potential fashion followers. Second, the British and Spanish accounting communities are of similar size; Gray and Helliar (1994) reported that the British accounting academic community was formed by 1,050 members in $1994^{1}$ whereas García, Gandía and Fuentes (1997) showed that the size of the Spanish

\footnotetext{
I The Register comprised accounting scholars but also academics who had Finance or Taxation as their sole areas of interest. British scholars were reckoned as members of the accounting community if their interests were either manifest in any field of accounting research or had taught any accounting subject. The total is detailed as follows: professors, 87 ; readers, 13; principal lecturers, 97; senior lecturers, 434; lecturers, 309; others, 110.
} 
accounting academia was of 806 members in that year ${ }^{2}$. Third, UK accounts for $21.04 \%$ of total contributions to top accounting journals during the observation period, so that we can fairly consider it as a high research profile national grouping. In comparison to the UK, countries, such as Spain, scoring less than $1 \%$ may intuitively be well classified into the category of low research profile communities. Support for this view is provided by testing the difference between means of the annual contributions to the 13 leading accounting journals by UK and Spain; the null hypothesis (Spain and UK have similar means in their contribution rates to the leading accounting journals) was rejected ( $\mathrm{p}<0.05)$. Fourth, the choice of Spain as subject of the study also rested on its cultural dissimilitudes with USA (see Hofstede, 1991). Such differences, we argue, make difficult for Spain to become a potential recipient of American initiated management accounting research fashions.

Figure 2 summarizes the impact of $\mathrm{ABC}$ on the British and Spanish accounting academic communities. It measures the proportion of $\mathrm{ABC}$-focused papers as a proportion of the total of management accounting articles published in the accounting journals of the observed countries. Proposition 1 contends that management accounting research fashions have a lower impact on communities with higher research profile than on their counterparts with a low one. The proposition is supported if there exists a significant difference in the proportion of $A B C$ papers published by each individual community as percentage of their articles with a management accounting focus. The data shown in Figure 3 suggests that $A B C$ had a higher impact on the Spanish accounting community than it had in its British counterpart. Whereas ABC-focused papers never exceeded 10\% (13 articles, 1992) of management accounting articles published in British accounting journals, Spanish accounting scholars have been substantially affected by the $\mathrm{ABC}$ research fashion; during the period 1993-1996, ABC-focused papers constituted a significant proportion of Spanish management accounting research, growing from $7.14 \%$ (1 article) in 1992 to $27.78 \%$

2 García et al. (1997) applied a stricter criterion to define members of the Spanish accounting academic community by only considering scholars who had taught accounting courses. The total is split as follows: Catedráticos de Universidad, 45 (Professors); Catedráticos de Escuela Universitaria, 17 (Professors of Undergraduate Schools); Profesores Titulares de Universidad, 101 (Associate Professors); Profesores Titulares de Escuela Universitaria, 188 (Associate Professors for Undergraduate Schools); Ayudantes de Universidad, 16 (Teaching Assistants); Ayudantes de Escuela Universitaria, 88 (Teaching Assistants); Profesores Asociados, 340 (Part time faculty); Becarios, 6 (lnterns); Otros, 5 (Others). 
(5 articles) in 1993, and peaking to $54.55 \%$ (18 articles) in 1994. Since then, ABCfocused papers have maintained a considerable share in the total of Spanish management accounting papers ( $40 \%$ of the total publication). Surprisingly, by sheer numbers, only one out of the $46 \mathrm{ABC}$-focused papers produced by the Spanish community had an empirical focus; the remaining 45 papers mainly dealt with topics such as $\mathrm{ABC}$ foundations, general surveys, the role of $\mathrm{ABC}$ in the new manufacturing environment, and the relationship of $\mathrm{ABC}$ with other costing systems.

------ FIGURE 2 TO APPEAR ABOUT HERE --------

Figure 3 highlights the adoption timing of $\mathrm{ABC}$ by the British and Spanish academic communities. It shows the accumulated frequency of $\mathrm{ABC}$ published papers in the accounting journals of the focal countries. Proposition 2 stated that national groupings with high research profile are earlier adopters of management accounting research fashions compared to their counterparts with lower profile. Such proposition is supported if there exists a significant delay in the pattern of adoption of $\mathrm{ABC}$ by the Spanish community compared to its British counterpart. The data shown in Figure 4 demonstrates that the Spanish accounting academic community was a later adopter of $\mathrm{ABC}$ compared to its British counterpart; Spain falls well behind Britain in the timing of embracing $A B C$ as a research agenda. First, the research significance of $A B C$ was clearly neglected by Spanish scholars until 1992 , as only $4.34 \%$ of the ABC papers were published in the period 1988-1992. Second, the British academic community followed an earlier, and smoother pattern of adoption of $\mathrm{ABC}$ by roughly concentrating $73 \%$ of its publications in the period 1993-1996.

FIGURE 3 TO APPEAR ABOUT HERE

\section{GENERAL DISCUSSION}

Despite the increasing interest in investigating the extant patterns of management accounting research and the vast contributions of the institutional sociology to educational organisations, little is known about the cross-national dynamics of accounting research ideas. The aim of this paper was to address the dynamics of the ebb and flow of management accounting research fashions across national groupings of accounting scholars. The results of this study are augmented by an empirical investigation of the British and Spanish academic communities during the period 1987-1996. Our analysis of the institutional sociology and management fashion 
literatures led us to argue that national groupings with high research profile are (i) less vulnerable to the effects of management accounting research fashions, and (ii) are earlier adopters of research fashions than their counterparts with lower research profile.

We have distinguished between national groupings with high and low research profile, and these categories were respectively exemplified by the cases of UK and Spain. We admit that the research profile of a given country cannot solely be attributed to technical criteria (e.g., research skills and education) but is also strongly influenced by a number of factors operating at the macro level (e.g., cultural, investment in $R \& D)$. Nevertheless, we contend that the magnitude of the research distance between the British and the Spanish accounting communities is not a general phenomenon when comparing other fields of inquiry. First, Lafuente and Oro (1992) collected data from the Institute for Science Information and reported that the contribution of Spain to hard sciences (e.g., physics, biology) increased from $0.9 \%$ in 1984 to $1.6 \%$ in 1990 , and peaked to $1.95 \%$ of total publications in 1992 . These figures are consistently higher than $0.21 \%$, which represents the share of the Spanish accounting academic community to its leading journals during the period 1987-1996. Second, Urrutia (1993) analysed the role of the Spanish economics and business administration communities in the global context by collecting data from the Social Sciences Citation Index. For the period 1986 to 1992 , he reported that British contributions were 40 times higher than those made by Spanish academics. In contrast, our data show that British accounting publications to the top 13 accounting journals were 100 times higher than those made by the Spanish national grouping for the observation period. In sum, these data reveal that the research distance between high and low research profile national groupings cannot only be explained by appealing to macro factors such as cultural differences.

Our findings conform with the proposition that high research profile groupings are less likely adopters of management accounting research fashions than their counterparts with lower research profile. These results have four additional implications. First, we concur with the notion that goal ambiguity is a driving force for imitation. In the particular case of the Spanish accounting academic community, we contend, ambiguity about the goals and boundaries of accounting research exists, 
especially if compared with the shared international standards of accounting research evaluation. Such ambiguity is explained by (i) The Spanish Ministry of Education developed a research evaluation assessment programme which began in 1990 and embraced all fields of knowledge. The programme was informed by international criteria of research evaluation such as impact indexes and publications in international refereed journals. In this context, fuzzy research goals of the accounting community were revealed by its overwhelming complaint against these criteria (e.g., a recurrent claim concerned the inclusion of textbooks at the highest category of the research evaluation criteria). As Whittington (1993: 388) reports, similar misunderstandings also occurred in the realm of the British community of accounting academics. However, the misunderstandings seemed to be limited in scope to faculty of new British universities, and (ii) the inconsistent editorial policy of most Spanish accounting journals; with the sole and recent exception of Revista Española de Financiación y Contabilidad, the remaining periodicals focus indistinctely on professional and research issues because accounting journals do not have consistent editorial policies. Second, consistent with the predictions of the institutional sociology and management fashion literatures, we suggest that the process of imitation of management accounting research fashions is also driven by uncertainty avoidance. Perceived uncertainty on research outcomes, we argue, is inversely related to the probability of short-term publishing. $\mathrm{ABC}$, thus, constitutes a reliable research topic to produce short-term publications on issues such as the foundations of the system and its role in the new manufacturing environment. Although these papers did not target leading accounting journals, it is worth considering that ambiguity in research goals within the academic community has some concomitant effect on the lack of incentives (e.g., promotion, salary increase) to conduct long-term research projects of uncertain results. As Frey (1993) argues, incentives in restricted academic markets (e.g., continental Europe) concern issues such as teaching excellence, interplay with the industry, and social mentorship. Third, adoption of management accounting research fashions has legitimatizing effects on scholars writing $\mathrm{ABC}$ papers. Other constituents of the national grouping (e.g., auditors, controllers, consultants, other scholars, and graduate students), as readers of outlets publishing ABC papers, regard their authors as change agents (Carnegie and Paker, 1996), that is, as experts who transfer innovative 
research ideas into the terrain of the national community. Fourth, evidence addressing the process of organizational imitation supports the notion that novel ideas are translated into their organisational and social contexts (see Zajac and Kraatz, 1993; Ezzamel, 1994; Genell, 1997). In contrast, we suggest that the dissemination of management accounting research fashions follows a more straightforward model of diffusion in which the imitator plays a more passive role (see DiMaggio and Powell, 1983). This departure from the translation model draws on the nature of the $A B C$ papers published in Spain; the overwhelming majority of publications deal with speculative issues rather than focusing on modelling or empirical matters. In explaining why we found such results, let us refer to one distinctive element of the imitation process. As Czarniawska and Joerges (1996) have noted, ideas are materialized through being written down. Management accounting fashion setters materialize their ideas through publications in accounting journals (e.g., the series of contributions made by the setters of $\mathrm{ABC}$ in the Journal of Cost Management). Publications of research fashion setters, we contend, are comprehensive and systematic, and constitute the canon of the fashion. Canons provide frameworks that leave few opportunities for research followers to elaborate deviations, especially in comparison with the scattered set of experiences that constitute the frame of reference for imitations in the business domain.

Our results indicate that national groupings with lower research profile are late adopters of management accounting research fashions. Two related considerations stem from these findings. First, it has been argued that "organizations seldom have direct experiences of the organizations or practices they imitate or refer to" (SahlinAnderson, 1996: 78). Although such contention fits well with the business realm, it is less convincing for higher education organisations whose structuration process is characterised by increasing interactions within the field (e.g., research networks, conferences, visits of scholars to other academic centers). Interactions provide a suitable venue for national groupings to disseminate their findings on the adoption of research fashions to counterparts. These interactions, however, identify status ordering (see DiMaggio and Powell, 1983) and provide useful insights to constituents of the organisational field about what fashions are being adopted by high research profile groupings and, thus, will be globally in vogue in the near future. Second, uncertainty 
avoidance is a determinant element in the adoption of research fashions and also plays a significant role in explaining the pattern of imitation. By relying on the superior knowledge of early adopters, low research profile groupings considerably reduce the risk of being involved in research fashions of low legitimatizing potential.

\section{Concluding Remarks}

The structuration of the accounting community at the international level has produced interesting contributions on the dynamics of accounting research. In this context, we have provided some insights into both the mobility of research fashions across countries and the characteristics that differentiate late from early adopters of research fashions. Our analysis was based on the contributions of the institutional sociology and management fashion literatures. Our study of research fashions dealt with the particular case of $\mathrm{ABC}$ and its effects on exemplars of high and low research profile accounting academic communities. In light with the arguments of the institutional sociology and management fashion literatures, we suggested that national groupings with high research profile are less vulnerable to the effects of research fashions than their counterparts with low research profile. We explained these differences by the interplay of the following arguments: ambiguity in goals and research boundaries, uncertainty avoidance about research outcomes, the legitimatizing effect of imitation before other constituents of the national grouping, and, lastly, we suggested that the pattern of imitation of low research profile groupings fits well into the category of diffussion models. We also concurred with the notion that low research profile groupings are later adopters of research fashions compared to their counterparts with high research profile. A supportive argument for this contention stated that interactions among constituents of the organisational field involve status ordering, which in turn brings about the observation of high profile research groupings by their low profile counterparts, particularly before making the adoption decision of a given research fashion.

Our paper also bears considerable limitations, which could encourage future work. First, empirical evidence has been collected from exemplars of high and low research profile national groupings. In this respect, future work on other national groupings will reveal the generalizability of our conclusions. Second, descriptive data are a common methodological problem of accounting research dealing with 
bibliometric databases (see Carnaghan, Flower-Gyepesi and Gibbins, 1994; Brown, 1996; Lukka and Kasanen, 1996; Shields, 1997 for some recent examples). Despite our genuine interest in overcoming such problem, we could not provide more compelling results due to the short-term nature of research fashions. This restrained us from using dynamic econometric models to account for the adoption lag of research fashions across national communities and introducing control variables into the models. Future research addressing longer research fashions or knowledge core (see Cole, 1983) may overcome such methodological problem. Third, we have studied research fashions by drawing on empirical evidence provided by publications in accounting journals. Evidence from other databases (e.g., citation analysis) may provide additional insights into the dynamics of life cycle of research fashions. Lastly, future research may provide further insights into the genesis of management accounting research fashions, especially by addressing how academics and practitioners influence each other (see Barley, Meyer and Gash, 1988), which constitutes a central issue in business research. 


\section{REFERENCES}

Abrahamson, E. (1991) Managerial Fads and Fashions: The Diffusion and Rejection of Innovations, Academy of Management Review, Vol.16, n³, pp. 586-612.

Abrahamson, E. (1996), Management Fashion, Academy of Management Review, Vol. $21 \mathrm{~N}^{\circ} 1$, pp. 254-285.

Arrington, C.E. and Schweiker, W. (1992), The Rhetoric and Rationality of Accounting Research, Accounting, Organizations and Society 17; pp. 511-533.

Atkinson, A.A.; Balakrishnan, R; Booth, P.; Cote, J.M.; Groot, T.; Malmi, T.: Roberts, H.; Uliana, E. and Wu, A. (1997) New Directions in Management Accounting Research, Journal of Management Accounting Research, 9: pp. 79-108.

Barley, S.R.; Meyer, G.W. and Gash, D.C. (1988), Cultures of Culture: Academics, Practitioners and the Dynamics of Normative Control, Administrative Science Quarterly, 33: 24-60.

Bikhchandani, S.; Hirshleifer, D. and Welch, I. (1992), A Theory of Fads, Fashion, Custom, and Cultural Change as Informational Cascades, Journal of Political Economy, Vol.100 No5, pp. 992-1026.

Brown, L.D. (1996), Influential Accounting Articles, Individuals, Ph.D. Granting Institutions and Faculties: A Citational Analysis, Accounting, Organizations and Society, Vol. $21 \mathrm{~N}^{\circ} 7 / 8$, pp. 723-754.

Brown, L.D. and Huefner, R.J. (1994). The Familiarity with and Perceived Quality of Accounting Journals: Views of Senior Accounting Faculty in Leading U.S. MBA Programs, Contemporary Accounting Research, Vol. 11 N¹-I (Summer): 223-250.

Callon, M. (1986), Some elements of a sociology of translation, in Law, J. (ed.) Power, Action and Belief(London: Routledge), pp. 196-233.

Carnaghan, C.; Flower-Gyepesi, J. and Gibbins, M. (1994), A Profile of Contemporary Accounting Research: Fall 1984-Spring 1994, Contemporary Accounting Research, Vol. 11 N¹-I (Summer) pp. 251-270.

Carnegie, G.D. and Parker, R.H. (1996), The Transfer of Accounting Technology to the Southern Hemisphere: The Case of William Butler Yaldwyn, Accounting, Business and Financial History (March), pp. 23-49.

Carruthers, B. (1995), Accounting, Ambiguity, and the New Institutionalism, Accounting, Organizations and Society, Vol. 20 N4, pp. 313-328.

Cole, S. (1983), The Hierarchy of the Sciences?, American Journal of Sociology, Vol. $89 \mathrm{~N}^{\circ} 1$, pp. 111-139. 
Cooper, R. and Kaplan, R.S. (1990) The Design of Cost Management Systems, (Englewood Cliffs, NJ: Prentice Hall).

Czarniawska, B. and Joerges, B. (1996), Travels of Ideas, in Czarniawska, B. and Sevón, G. (eds.), Translating Organizational Change, (Walter de Gruyter: Berlin), pp. $13-48$.

DiMaggio, P.J. (1983), State Expansion and Organizational Fields, in R.H. Hall and R.E. Quinn (eds.) Organizational Theory and Public Policy (Beverly Hills, CA: Sage) pp. 141-172.

DiMaggio, P.J. and Powell, W.W. (1983), The Iron Cage Revisited: Institutional Isomorphism and Collective Rationality in Organizational Fields, American Sociological Review, 48: pp.147-160.

Ezzamel, M. (1994), Organizational change and accounting: Understanding the Budgeting System in its Organizational Context, Organization Studies 15/2, pp. 213 240.

Frey, B.S. (1993), An Institutional Analysis of the New Institutional Economics, Journal of Institutional and Theoretical Economics, 149/1, pp. 351-359.

Frey, B.S. and Eichenberger, R. (1993), American and European Economics and Economists, Journal of Economic Perspectives, Vol. 7 No4 (Fall), pp. 185-193.

García Benau, M.A.; Gandía Cabedo, J.L. and Fuentes, C. (1997), Grado de satisfacción de los profesores universitarios de contabilidad con la carrera académica, Revista Española de Financiación y Contaibilidad (91); pp. 541-575.

Genell, K. (1997), Transforming Management Education: A Polish Mixture (Lund: Lund University Press).

Gómez-Mejía, L.R. and Balkin, D. (1992) Determinants of Faculty Pay: An Agency Theory Perspective, Academy of Management Journal, Vol. 35 N5, pp. 921-955.

Gray, R.H. and Helliar, C. (1994), The British Accounting Review Research Register (London: Academic Press).

Gray, R.H. and Helliar, C. (1994), UK Accounting Academics and Publication: An Exploration of Observable Variables Associated wih Publication Output, British Accounting Review, 26: 235-254.

Hofstede, G. (1991), Cultures and Organizations: Software of the Mind (McGraw Hill: London).

Humprey, C.; Moizer, P. and Owen, D. (1995), Questioning the Value of the Research Selectivity Process in British University Accounting, Accounting, Auditing and Accountability Journal, Vol. 8 No.3: 141-164. 
Lafuente, A. and Oro, L.A. (1992), El sistema español de ciencia y tecnología en el marco internacional (Madrid: Fundesco).

Latour, B. (1986), The Powers of Association, in Law, J. (ed.) Power, Action and Belief (London: Routledge), pp.261-277.

Lee, T. (1989). Education, Practice and Research in Accounting: Gaps, Closed Loops, Bridges and Magic Accounting, Accounting and Business Research, Vol. 19 N$^{\circ} 75$ : 237-253.

Lukka, K. and Kaasanen, E. (1996), Is Accounting a Global or a Local Discipline? Evidence from Major Research Journals, Accounting, Organizations and Society, Vol. $21 \mathrm{~N}^{\circ} 7 / 8$, pp. 755-773.

Meyer, J.W. and Rowan, B. (1977), Institutionalized organizations: Formal structure as myth and ceremony, American Journal of Sociology, 83: 340-363.

Meyer, J.W. and Scott, R.S. (1983), Organizational Environments: Ritual and Rationality (Beverly Hills: Sage)

Mezias, S.J. and Scarseletta, M. (1994), Resolving Financial Reporting Problems: An institutional analysis of the process, Administrative Science Quarterly, 39: pp. 654678.

Napier, C.J. (1996), Accounting and the Absence of a Business Economics Tradition in the United Kingdom, The European Accounting Review, Vol. 5 N'3: pp. 449-481.

Näsi, S and Näsi, J. (1997), Accounting and Business Economics Traditions -from a Practical Discipline into a Scientific Subject and Field of Discipline, The European Accounting Review, Vol. 6 No2, 199-229.

Oliver, C. (1991), Strategic Responses to Institutional Processes, Academy of Management Review, 16: 145-179.

Parker, L.D.; Guthrie, J. and Gray, R.H. (1997), Publish or Perish: The Social Construction of Quality in Accounting and Management Research.

Panozzo, F. (1997), The Making of the Good Academic Accountant, Accounting, Organizations and Society, Vol.22 N5, pp. 447-480.

Pfeffer, J. (1993), Barriers to the Advance of Organizational Science: Paradigm Development as a Dependent Variable, Academy of Management Review, Vol.18 No4, pp. 599-620.

Puxty, A.G., Sikka, P. and Willmott, H.C. (1994). Systems of Surveillance and the Silencing of UK Academic Accounting Labour, British Accounting Review, 26: 137 171. 
Rowan, B.(1982), Organizational Structure and the Institutional Environment: The Case of Public Schools, Administrative Science Quarterly, 27, pp. 259-279.

Sahlin-Anderson, K. (1996), Imitating by Editing Success: The Construction of Organizational Fields, in in Czarniawska, B. and Sevón, G. (eds.) Translating Organizational Change (Walter de Gruyter: Berlin), pp. 69-92.

Schneider, B. (1995), Some Propositions About Getting Research Published, in Cummings, L.L. and Frost, P.J. (eds.), Publishing in the Organizational Sciences (Thousand Oaks, CA: Sage) 216-226.

Schultz, J.Jr., meade, J.A. and Khurana, I. (1989). The Changing Roles of Teaching, Research, and Service in the Promotion and Tenure Decisions for Accounting Faculty, Issues in Accounting Education (Spring): 109-119.

Sevón, G. (1996), Imitating by Editing Success: The Construction of Organizational Fields, in Czarniawska, B. and Sevón, G. (eds.) Translating Organizational Change (Walter de Gruyter: Berlin), 49-67.

Shields, M.D. (1997) Research in Management Accounting by North Americans in the 1990s, Journal of Management Accounting Research, 9: 3-61.

Stigler, G. and Becker,G. (1977), De Gustubis Non Est Disputandum, American Economic Review (March), pp.76-90.

Urrutia, J. (1993), La investigación española en economía, Política Cientifica, 36; pp. 41-47.

Whitley, R. (1984) The Intellectual and Social Organization of the Sciences (Oxford: Oxford University Press).

Whittington, G. (1993), Education and Research Notes: The 1992 Research Assessment Exercise, British Accounting Review Vol. 25 No.4; pp. 383-395.

Zambon, S. (1996), Accounting and Business Economics Traditions: A Missing European Connection, The European Accounting Review, Vol. 5 N³, pp.401-411.

Zajac, E.C. and Kraatz, M.S. (1993), A Diametric Forces Model of Strategic Change: Assessing the Antecedents and Consequences of Reestructuring the Firm in the Higher Education Industry, Strategic Management Journal, Vol. 14: pp.83-102.

Zeff, S.A. (1989), Recent Trends in Accounting Education and Research in the USA: Some Implications for UK Academics, British Accounting Review (June): 159-176. 


\begin{tabular}{|c|c|c|c|c|c|c|c|c|c|c|c|}
\hline & \multicolumn{9}{|c|}{ TABLE 1: CONTRIBUTIONS TO TOP ACADEMIC JOURNALS BY COUNTRIES } & \multirow[b]{2}{*}{1996} & \multirow[b]{2}{*}{ TOTAL } \\
\hline & 1987 & 1988 & 1989 & 1990 & 1991 & 1992 & 1993 & 1994 & 1995 & & \\
\hline ARAB EMIRATES & 0,00 & 0,00 & 0,00 & 0,00 & 0,00 & 0,00 & 0,23 & 0,00 & 0,00 & 0,00 & 0,03 \\
\hline AUSTRALIA & 9,25 & 7,88 & 11,09 & 7,09 & 5,39 & 6,89 & 4,97 & 5,78 & 7,17 & 6,75 & 6,95 \\
\hline AUSTRIA & 0,00 & 0,00 & 0,00 & 0,43 & 0,00 & 0,00 & 0,55 & 0,29 & 0,15 & 0,54 & 0,23 \\
\hline BAHREIN & 0,00 & 0,00 & 0,00 & 0,00 & 0,00 & 0,00 & 0,00 & 0,00 & 0,30 & 0,00 & 0,03 \\
\hline BELGIUM & 0,00 & 0,00 & 0,00 & 0,00 & 0,33 & 1,07 & 1,38 & 0,73 & 0,60 & 0,90 & 0,60 \\
\hline BRUNEI & 0,00 & 0,00 & 0,00 & 0,43 & 0,00 & 0,31 & 0,00 & 0,00 & 0,00 & 0,00 & 0,07 \\
\hline CANADA & 2,10 & 4,60 & 2,58 & 5,74 & 6,12 & 7,82 & 6,31 & 7,96 & 4,46 & 5,19 & 5,57 \\
\hline CHINA & 0,00 & 0,74 & 0,00 & 0,21 & 0,00 & 0,15 & 0,00 & 0,00 & 0,00 & 0,27 & 0,12 \\
\hline COSTA RICA & 0,00 & 0,00 & 0,00 & 0,00 & 0,00 & 0,00 & 0,00 & 0,00 & 0,00 & 0,00 & 0,00 \\
\hline CYPRUS & 0,00 & 0,00 & 0,00 & 0,00 & 0,00 & 0,00 & 0,00 & 0,00 & 0,00 & 0,00 & 0,00 \\
\hline CZECH R & 0,00 & 0,00 & 0,00 & 0,00 & 0,00 & 0,00 & 0,00 & 0,00 & 0,40 & 0,09 & 0,06 \\
\hline DENMARK & 0,00 & 0,00 & 0,00 & 0,00 & 0,17 & 0,61 & 1,11 & 0,58 & 0,15 & 1,09 & 0,45 \\
\hline ESTONIA & 0,00 & 0,00 & 0,00 & 0,00 & 0,00 & 0,00 & 0,00 & 0,00 & 0,07 & 0,00 & 0,01 \\
\hline FIJI & 0,00 & 0,00 & 0,00 & 0,00 & 0,11 & 0,06 & 0,00 & 0,00 & 0,00 & 0,00 & 0,02 \\
\hline FINLAND & 0,00 & 0,49 & 0,43 & 0,00 & 1,00 & 0,31 & 1,38 & 0,99 & 1,79 & 2,17 & 0,98 \\
\hline FRANCE & 0,00 & 0,00 & 0,00 & 0,00 & 0,50 & 0,61 & 1,50 & 0,87 & 1,49 & 1,08 & 0,72 \\
\hline GERMANY & 0,00 & 0,00 & 0,21 & 0,00 & 0,00 & 1,53 & 0,55 & 0,97 & 0,60 & 1,09 & 0,58 \\
\hline GREECE & 0,00 & 0,00 & 0,00 & 0,00 & 0,00 & 0,00 & 0,00 & 0,29 & 0,00 & 0,27 & 0,07 \\
\hline HOLLAND & 0,00 & 0,99 & 0,00 & 0,00 & 0,00 & 0,77 & 0,83 & 1,02 & 0,90 & 0,59 & 0,56 \\
\hline HONG KONG & 0,00 & 0,00 & 0,21 & 0,00 & 1,34 & 0,92 & 1,15 & 0,29 & 2,64 & 0,95 & 0,87 \\
\hline HUNGARY & 0,00 & 0,00 & 0,00 & 0,00 & 0,00 & 0,00 & 0,00 & 0,00 & 0,10 & 0,27 & 0,05 \\
\hline INDIA & 0,00 & 0,00 & 0,00 & 0,00 & 0,00 & 0,25 & 0,00 & 0,00 & 0,00 & 0,00 & 0,03 \\
\hline IRELAND & 0,27 & 0,49 & 0,21 & 0,43 & 0,00 & 0,61 & 0,00 & 0,00 & 0,45 & 0,27 & 0,26 \\
\hline ISRAEL & 1,10 & 1,23 & 1,07 & 0,85 & 0,50 & 0,15 & 0,37 & 0,15 & 0,20 & 0,36 & 0,51 \\
\hline ITALY & 0,00 & 0,00 & 0,00 & 0,00 & 0,00 & 0,00 & 0,28 & 0,29 & 0,00 & 0,36 & 0,12 \\
\hline JAPAN & 0,00 & 0,00 & 0,00 & 1,91 & 1,22 & 0,00 & 0,28 & 0,82 & 0,70 & 0,36 & 0,54 \\
\hline JORDAN & 0,00 & 0,00 & 0,43 & 0,00 & 0,11 & 0,00 & 0,00 & 0,00 & 0,00 & 0,00 & $0, \overline{05}$ \\
\hline KENYA & 0,00 & 0,00 & 0,00 & 0,00 & 0,00 & 0,00 & 0,00 & 0,15 & 0,00 & 0,00 & 0,02 \\
\hline KUWAIT & 0,00 & 0,49 & 0,43 & 0,85 & 0,00 & 0,00 & 0,00 & 0,00 & 0,00 & 0,00 & 0,14 \\
\hline LAGOS & 0,00 & 0,00 & 0,43 & 0,00 & 0,00 & 0,00 & 0,00 & 0,00 & 0,00 & 0,00 & 0,03 \\
\hline LATVIA & 0,00 & 0,00 & 0,00 & 0,00 & 0,00 & 0,00 & 0,00 & 0,00 & 0,07 & 0,00 & 0,01 \\
\hline LIBYA & 0,00 & 0,00 & 0,21 & 0,00 & 0,00 & 0,10 & 0,00 & 0,00 & 0,00 & 0,00 & 0,03 \\
\hline LITHUANIA & 0,00 & 0,00 & 0,00 & 0,00 & 0,00 & 0,00 & 0,00 & 0,00 & 0,07 & 0,27 & 0,04 \\
\hline MALAISYA & 0,00 & 0,00 & 0,00 & 0,00 & 0,00 & 0,00 & 0,51 & 0,00 & 0,00 & 0,00 & 0,06 \\
\hline N.ZEALAND & 0,55 & 3,20 & 1,93 & 0,43 & 0,50 & 1,07 & 1,61 & 2,09 & 1,05 & 1,50 & 1,39 \\
\hline NIGERIA & 0,00 & 0,00 & 0,00 & 0,00 & 0,00 & 0,00 & 0,00 & 0,00 & 0,00 & 0,00 & 0,00 \\
\hline NORWAY & 0,00 & 0,00 & 0,21 & 0,00 & 0,00 & 0,61 & 0,35 & 0,10 & 0,15 & 0,00 & 0,16 \\
\hline PERU & 0,00 & 0,00 & 0,00 & 0,00 & 0,00 & 0,00 & 0,00 & 0,00 & 0,00 & 0,14 & 0,02 \\
\hline POLAND & 0,00 & 0,00 & 0,00 & 0,00 & 0,00 & 0,00 & 0,28 & 0,10 & 0,40 & 0,00 & 0,09 \\
\hline ROMANIA & 0,00 & 0,00 & 0,00 & 0,00 & 0,00 & 0,00 & 0,00 & 0,00 & 0,30 & 0,00 & 0,03 \\
\hline RUSSIA & 0,00 & 0,00 & 0,00 & 0,00 & 0,00 & 0,00 & 0,00 & 0,00 & 0,45 & 0,54 & 0,12 \\
\hline SINGAPORE & 0,55 & 0,74 & 0,21 & 0,85 & 0,78 & 0,71 & 0,51 & 0,44 & 1,00 & 0,00 & 0,57 \\
\hline SLOVENIA & 0,00 & 0,00 & 0,00 & 0,00 & 0,00 & 0,00 & 0,00 & 0,00 & 0,30 & 0,00 & 0,03 \\
\hline S. AFRICA & 0,00 & 0,00 & 0,57 & 0,00 & 0,00 & 0,00 & 0,00 & 0,00 & 0,00 & 0,00 & 0,05 \\
\hline S. KOREA & 0,00 & 0,00 & 0,21 & 0,00 & 0,67 & 0,31 & 0,14 & 0,44 & 0,55 & 0,45 & 0,31 \\
\hline SPAIN & 0,00 & 0,00 & 0,43 & 0,00 & 0,00 & 0,46 & 0,64 & 0,36 & 0,00 & 0,00 & 0,21 \\
\hline SUDAN & 0,00 & 0,00 & 0,43 & 0,00 & 0,00 & 0,00 & 0,00 & 0,00 & 0,00 & 0,00 & 0,03 \\
\hline SWEDEN & 0,00 & 1,48 & 1,07 & 1,28 & 0,33 & 0,00 & 1,94 & 1,02 & 0,00 & 0,54 & 0,76 \\
\hline SWITZERLAND & 0,27 & 0,00 & 0,00 & 0,00 & 0,00 & 0,00 & 0,28 & 0,29 & 0,60 & 0,23 & 0,18 \\
\hline TAIWAN & 0,00 & 0,00 & 0,00 & 0,00 & 0,00 & 0,00 & 0,64 & 0,00 & 0,25 & 0,00 & 0,11 \\
\hline THAILANDIA & 0,00 & 0,00 & 0,00 & 0,43 & 0,00 & 0,00 & 0,00 & 0,00 & 0,00 & 0,00 & 0,03 \\
\hline UK & 23,26 & 16,09 & 19,03 & 16,17 & 20,58 & 22,29 & 19,63 & 19,37 & 23,99 & 26,57 & 21,04 \\
\hline USA & 62,64 & 61,58 & 58,59 & 62,91 & 60,35 & 52,38 & 52,59 & 54,60 & 48,67 & 47,15 & 55,05 \\
\hline TOTAL & 100,00 & 100,00 & 100,00 & 100,00 & 100,00 & 100,00 & 100,00 & 100,00 & 100,00 & 100,00 & 100,00 \\
\hline SOURCE: Auth & & & & & & & & & & & \\
\hline
\end{tabular}




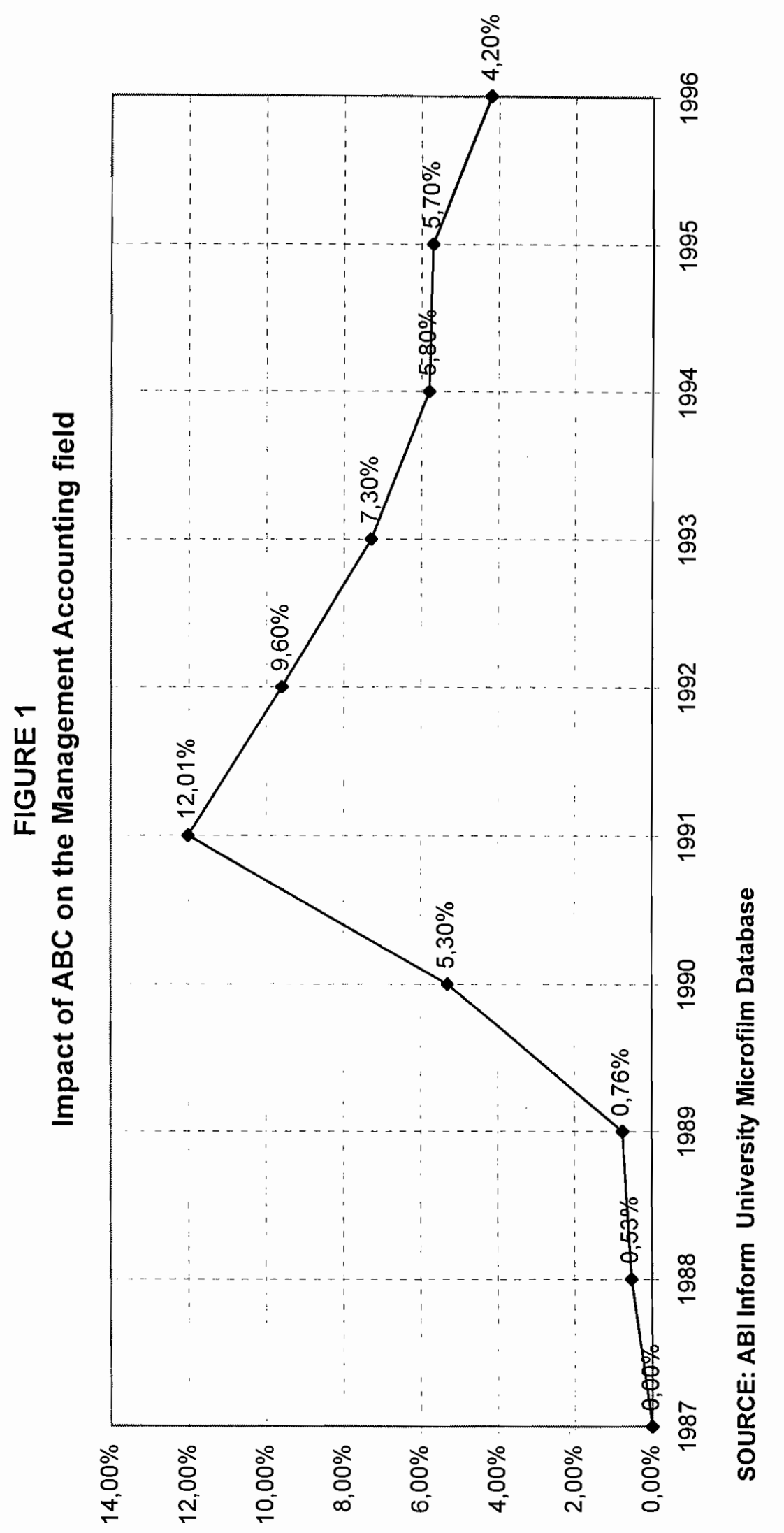




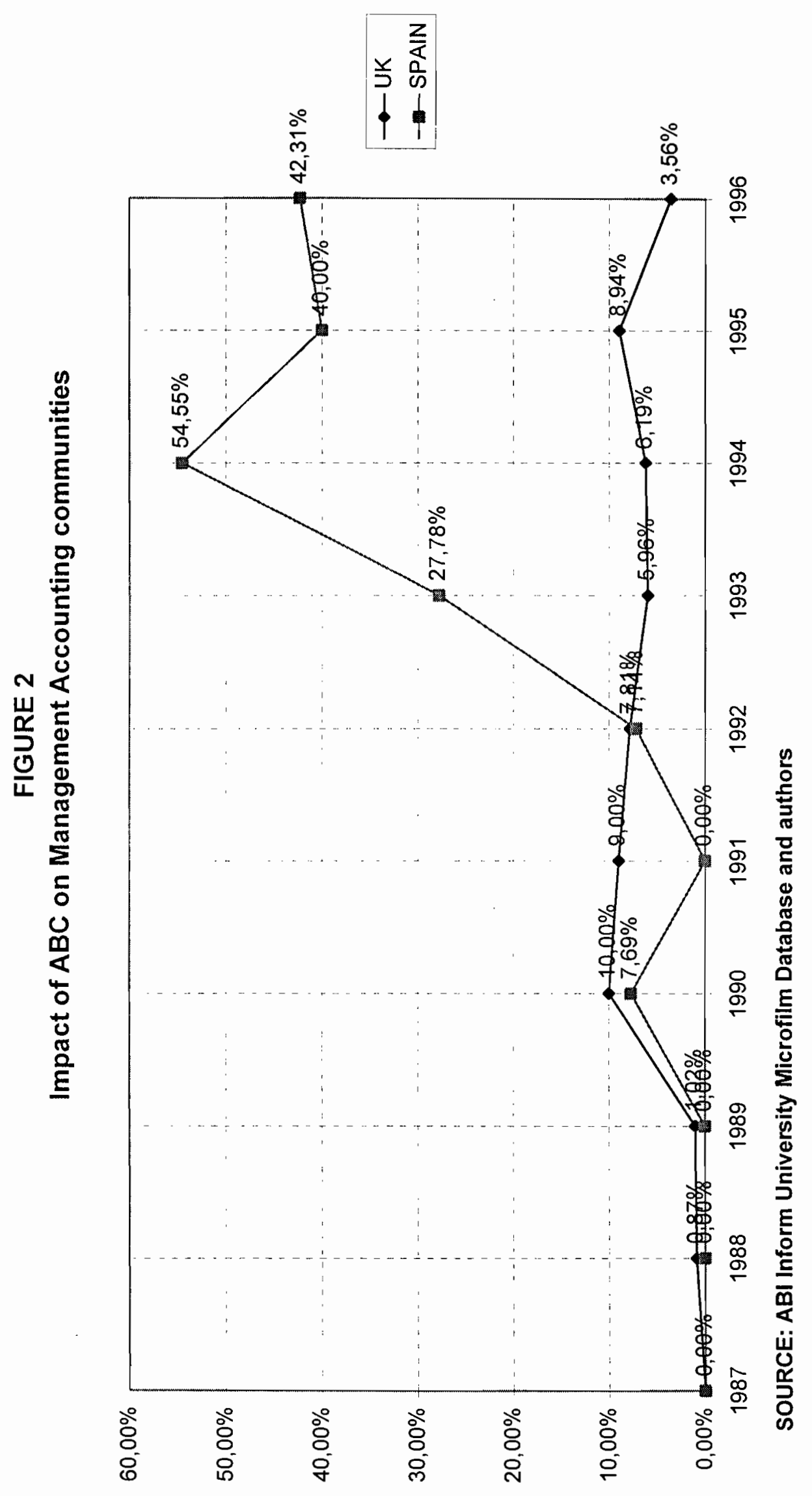




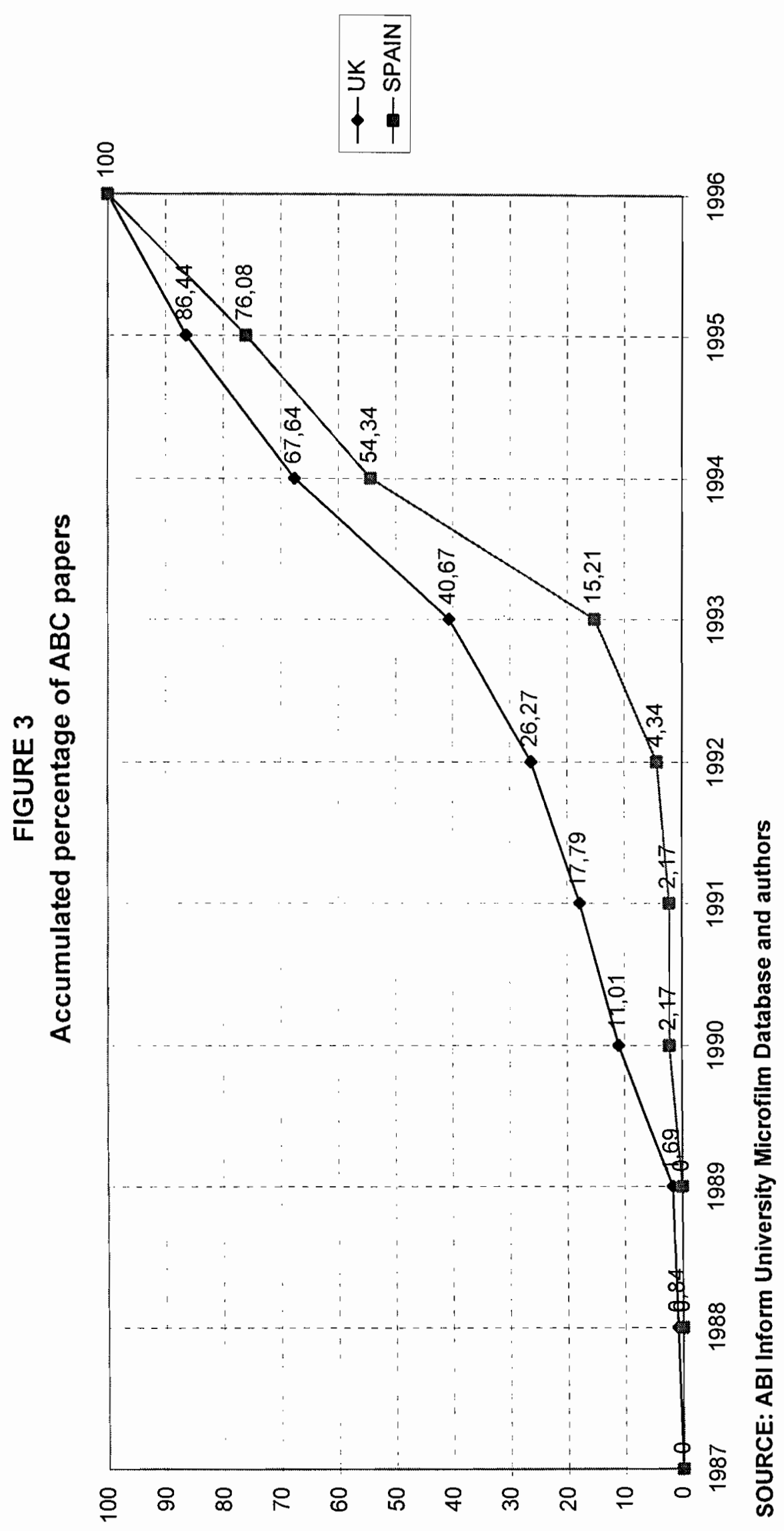




$$
\text { . }
$$

